\title{
What a Shame! Memoirs of a Time of Queer Immaturity: Prologue
}

Błażej Warkocki 


\section{What a Shame! Memoirs of a Time of Queer Immaturity: Prologue}

DOI:10.18317/td.2018.en.1.12

\section{The Hidden Memoir}

Witold Gombrowicz's debut short story collection, $\mathrm{Mem}$ oirs from a Time of Immaturity, has been analyzed and examined from all possible angles. We know that after being rejected by a number of publishers, Gombrowicz eventually used his father's money to self-publish the collection and that it stirred up a lot of excitement in literary and critical circles. We also know that the title turned out to be so bothersome, that the author himself decided against using it for post-war editions of the collection, replacing it with a nonsense word containing a peculiarly suspended reference: Bacacay.

The following deliberations are based around the hypothesis posited by Ewa Graczyk in the opening of her monograph, Shake Before Exploding, exploring Gombrowicz's pre-war efforts. Graczyk claims that the interpretative starting point should comply, at least to some degree, with the "Purloined Letter" rule, in other words, that the title - Memoirs from a Time of Immaturity - should be read literally. The hypothesis can naturally be rejected, but one has to use it as a sort of jump-off point to some extent against subsequent attempts - also on the part of the author himself - to erase the meaning of that phrase.
Błażej Warkocki -

Assistant Professor at the Anthropology of Literature

Department at the Adam Mickiewicz University and a literary critic. $\mathrm{He}$ is the author of Pink Language: Literary and Cultural Policies in Early 21st Century (2013) and Homo niewiadomo: Polish Prose and Queerness (2007), co-author (with P. Czapliński, E. Szybowicz, and M. Leciński) of the 1976-2000 Almanac of Literary Life: Events - Discussions Statements, and coeditor of Polish Homophobia (2004). 
Graczyk writes: "Let us assume that at least in some sense, the Memoirs are essentially a sort of diary written by an individual undergoing a coming of age. Let us assume that the narrative inconsistency, the non-identity of characters, and the separate and singular character of each of the stories all conceal a sort of congruence that is both textual as well as subjective (in the sense of the establishment of a single subject across the entire collection). Let us preliminarily accept the hypothesis that the Memoirs are a series of texts, arranged in a specific, deliberate order of appearance. Besides the arrangement, the stories are connected at a very basic level by another feature - one ostensibly more important than the arrangement - namely the appearance of a number of echoes and correlations that emerge when the collection is read as a whole."1The scholar presumes that the text is consistent both formally and substantively. Therefore, as a consequence of the above: "I believe that if we treat the book as a narrative with a single subject, then the covert preservation of the integrity of the Memoirs in Bacacay will emerge as a very significant decision. It will then become clear that Gombrowicz was deeply ambivalent about that particular volume: he guarded the consistency of the message and simultaneously concealed it, hampering efforts aimed at reading or deciphering it. In a sense, he confined and imprisoned the Memoirs in Bacacay."2

Graczyk's use of nearly Gothic rhetoric ("confine," "imprison") is not without its significance. Moreover, somewhat against the author's wishes, she instructs us to take the title of the collection literally. Such interpretative efforts should remind of us of the exploits of the Detective from Edgar Allan Poe's highly acclaimed story The Purloined Letter, interpreted by Lacan and Derrida and extensively used by Polish scholars in interpretations inspired by queer theory. ${ }^{3}$ The truth is up on the surface, and the memoir is a memoir - a grotesque, inconsistent, masochistic biography of subjectivity itself. In line with the etymology, it is an account of what is remembered. A record of negative affects. ${ }^{4}$

1 Ewa Graczyk, Przed wybuchem wstrzq̨snąć. O twórczości Witolda Gombrowicza w okresie międzywojennym (Gdańsk: słowo/obraz terytoria, 2004), 8.

2 Ibid., 9.

3 These include Izabela Filipiak, Obszary odmienności. Rzecz o Marii Komornickiej (Gdańsk: słowo/obraz terytoria, 2006) and Joanna Niżyńska, The Kingdom of Insignificance: Miron Białoszewski and the Quotidian, the Queer, and the Traumatic (Evanston: Northwestern University Press, 2013).

4 This hypothesis is confirmed, though in different language, by Jerzy Jarzębski: "Through the entirety of Memoirs from a Time of Immaturity, the author plays a subtle game with literature itself, invoking names of great authors, such as Poe or Dostoyevsky, writers fascinated with the ambiguity of human expression of the unconscious, with the codes used by the deep «self» to express itself. Gombrowicz also plays with his own image, as it is in- 
The title of Gombrowicz's debut has stirred up excitement and concern since its very release. As put by Zdzisław Łapiński:

\begin{abstract}
Although it may seem strange now, both Gombrowicz and his close friends believed that the title of the anthology may be perceived as an attempt to toy with public opinion, an endeavor not without its dangers. Their fears eventually materialized and the category of immaturity, the full extent of its complexity to be revealed only in Ferdydurke, although fairly good samples of it can already be found in the Memoirs, has been recognized not as a problem that the author has posed, but rather as an inadvertent symptom, an expression of inexperienced awkwardness in one's treatment of life, literature, and oneself.5
\end{abstract}

It is fairly difficult to grasp today why Memoirs from a Time of Immaturity could have been considered such a dangerous title and why anyone would perceive immaturity as such an inappropriate category or label (especially given the fact that it was further developed, to great success, by the author in Ferdydurke). Unless, to use the "Purloined Letter" approach, it is not immaturity that was problematic in the context of the title (suggesting a relationship between the narrators and the author), but rather a sort of "abnormality" or - to use a more modern phrase - "non-normativity." It is difficult not to notice that the characters in the novellas are rarely normative, they touch upon rather non-normative affects and states, and we could - although not without difficulty - incorporate them in some sort of heterosexual teleology. And that is another thing that breathes a measure (however limited) of consistency into the series.

In and of itself, however, "immaturity" is a fairly suspect category - particularly if it appears as the eponymous key to the "memoirs" of a not-thatyoung of an author (Gombrowicz was 29 when his debut was released). More so if we consider the accusations of "sexualism" and "Freudism" from some readers, ${ }^{6}$ which Gombrowicz himself fearfully anticipated in the prologue that

troduced into individual stories in different version, under the guise of characters suffering from problems similar to the author. The voice of the author (although changed to some extent) can be heard in the mouths of the «dancer», Jakub Czarniecki, the investigative judge, the protagonist of Five Minutes beforeSleep, Zantman, and Alice from Virginity. From his first book onwards, masked self-presentation will become Gombrowicz's specialty." Jerzy Jarzębski, Gombrowicz (Wrocław: Wydawnictwo Dolnośląskie, 2004), 33-34.

5 Zdzisław Łapiński, /a - Ferdydurke, Gombrowicza świat interakcji (Lublin: Wydawnictwo Katolickiego Uniwersytetu Lubelskiego, 1985), 21-22.

6 The popular and critical reception of the Memoirs was examined by Jerzy Jarzębski in Gra w Gombrowicza (Warszawa: PIW, 1982). 
was eventually removed from the book. If we were to look at Freud's "cases" as revealing the historicity of narrative, then we would have uncovered the perils lurking in the implications of "immaturity." One such example would be the "Schreber case," wherein Freud thematized (male) homosexuality and its relationship with the concept of the Gothic. Hence, were we to look at the trajectory along which the subject develops over the course of the narrative, we would have discovered a journey, a pilgrimage, or maybe a particular kind of "odyssey" (given that Freud was extremely well-versed in antiquity). Put in another way, normative heterosexuality, in Freud's work, is achieved over the course of a specific odyssey. There are a number of intermediate stages on the road to maturity - to heterosexuality, that is - and one can get slowed down, delayed, or even bogged down, and not out of one's own volition either, like Odysseus enthralled by the Sirens' song. And so the maturing subject journeys through the autoeroticism stage, the narcissism stage, and the possibly inevitable homosexual object choice stage, eventually arriving at the final, heterosexual stage. The maturing subject, however, can stop at any of these stages, fixate on them, enraptured by the Sirens' call, and thus never reach the Ithaca of heterosexuality. ${ }^{7}$

This particular paraphrase is not supposed to prove that Freudian psychoanalysis $^{\mathbf{8}}$ is the supreme interpretative key with which to examine Gombrowicz's debut, but rather that an oblique, suspicious reading of "Freud's cases" (one that is consistent with the logic of the narrative) may provide a degree of explanation for widespread anxiety concerning the debut. More so given the fact that subsequent novellas contained in the Memoirs from a Time of Immaturity indeed seem fairly impervious to heterosexual teleologies and heteronormativity. Resistance against being saddled with typical male roles, the bashful fascination with solicitor Kraykowski, the masochisms, the "homosexual panic"9 spreading across a ship full of men, or the absolute inability to imagine oneself in a heterosexual marriage (on the part of Alice in Virginity) - these are the subjects that this particular memoir deals with.

7 Sigmund Freud, "Psychoanalityczne uwagi o autobiograficznie opisanym przypadku paranoi (dementia paranoides)" in Sigmund Freud, Charakter a erotyka, trans. Robert Reszke and Dariusz Rogalski (Warszawa: Wydawnictwo KR, 1996). This "odyssey towards heterosexuality" is especially visible in the interpretation part of the "Schreber case," 148-149.

8 Especially given the resistance with which psychoanalysis was met in Poland. See Paweł Dybel, "Urwane ścieżki, czyli z dziejów psychoanalizy w Polsce," in Paweł Dybel, Urwane ścieżki. Przybyszewski - Freud - Lacan (Kraków: Universitas, 2000).

9 See Tomasz Kaliściak, "Statek odmieńców, czyli o marynarskiej fantazji Witolda Gombrowicza," in Literatura popularna. Dyskursy wielorakie, ed. Ewa Bartos and Marta Tomczok, (Katowice: Wydawnictwo Uniwersytetu Śląskiego, 2013). 
In this context, let us take a closer look at the author's own foreword to the book which seems more odd than any of the seven novellas that follow it. The not-so-young author initially opened his debut with an introduction curiously titled "A Brief Explanation." Shortly before publication, however, he scrapped the introduction, even though some claim - including Tadeusz Kępiński - that at least a couple of 1933 editions were released with the opening chapter intact. ${ }^{10}$ From a formal standpoint, the introduction contains a meticulous overview of the novellas making up the book and lays out their interpretation. In careful paragraphs, the author expounds on the contents of the texts and how they should be understood. Why did Witold Gombrowicz, a writer with considerable literary ambition, decide to commit such a questionable gesture? Why did this sophisticated master of the written word involve himself with an attempt to explain to his readers what exactly he was trying to say in his novellas? The answer probably lies in the communication strategy itself: he was not interested in enlightening all readers, but a specific subset of them. In his own words: 'My friends' opinion of my person is of great import to me."11 Indeed, family and friends may end up reading one's work with a more biographical inclination than any author would intend. And Gombrowicz's "A Brief Explanation" could be considered, to borrow a term from psychoanalysis, as a peculiar example of countertransference.12 In this instance, the author - fearing imagined projections (about both his work and his person) - drafts an interpretation of his own short stories. In other words: such an effort would imply a self-interpretation in response to imagined projections. That is why it seems so defensive and agreeable, so to speak. The stories are "written somewhat evasively," admits Gombrowicz, there is nothing odd or peculiar about them, and the "prevalence" of the sexual themes stems purely from the "spirit of the times."13 The big Other, friends and parents who financed the book ought to be satisfied. There is nothing

10 Tadeusz Kępiński, Witold Gombrowicz i świat jego młodości (Kraków: Wydawnictwo Literackie, 1976), 314. Ibid., 314. Tadeusz Kępiński included "A Brief Explanation" on pages 314-318.

12 Jean Laplanche and Jean-Bertrand Pontalis, Słownik psychoanalizy, trans. Ewa Modzelewska and Ewa Wojciechowska (Warszawa: Wydawnictwa Szkolne i Pedagogiczne, 1996), 253-254. This Freudian term (although one that Freud himself rarely used) is described as "the entirety of the analyst's unconscious reactions to the individual analyzed - especially to the analyzed's own transference," p. 253.

13 In the final paragraph we read: "As far as the sexual factor is concerned, its prevalence stems from the spirit of the times, which puts an ever-growing emphasis on the relationship between the sexual and the spiritual," ibid., 318. It is a direct (although critical) reference to the Freudian concept of sublimation. 
to fear. However, this counterprojection indirectly validates Ewa Graczyk's hypothesis that the Memoirs have more than one (non-normative) subject.

Towards the end we should examine one more piece of proof. A trifle from the perspective of formality (and trifles, as detective narratives have hammered into us, are usually of first rate importance). The final story in the $\mathrm{Mem}$ oirs was called The Events on the Banbury. In the redesigned anthology released after the war under the new, impenetrable title Bacacay, The Events on the Banbury is no longer the last story and loses its subtitle (...or the Aura of F.Zantman's Mind). Thus, the line connecting the first and final stories in the anthology, the former being, naturally, Solicitor Kraykowski's Dancer, is severed. Well, how were the two connected? As noticed by Knut Andreas Grimstad,14 "Zantman," the name of one of the passengers traveling on the Banbury is an anagram of the German word "tanzman" or "dancer." And given that the dancer appears already in the title of the opening story of the anthology, Solicitor Kraykowski's Dancer, it is hard to think that this was just a coincidence. But before we move on, we will bring up two specific issues: in this somewhat covert way, Gombrowicz emphasized and strengthened the integrity of the anthology suggesting a common thread running through all the stories; and secondly, by doing away with the subtitle of The Events on the Banbury, thus removing it from its semantically distinctive placement in the tail end of the anthology, Gombrowicz essentially (to use the phrase coined by Ewa Graczyk) "imprisoned the Memoirs in Bacacay."

\section{Savage Shame}

Solicitor Kraykowski's Dancer, the first short story in Gombrowicz's debut anthology, is a first-person narrative about shame that, once inflicted, leaves a lifelong mark, interpellates identity, provides a framework for social interaction, mediates the experience of pleasure, and eventually kills - at least in the narrative's fantasy scenario. In this case, however, shame functions differently from what we would expect based on reasonable scenarios. In consequence, it does not produce alienation and estrangement (of all that we would intuitively associate with e $\mathrm{m}$ b a r r a s s m e $\mathrm{nt}$ ). On the contrary, it drives the action, obsessive activity, and acting out. Thereby, the Dancer is a tale about shame and about what Sedgwick has called queer performativity. ${ }^{15}$

14 Knut Andreas Grimstad, "Co się zdarzyło na brygu Banbury? Gombrowicz, erotyka i prowokacja kultury," trans. Olga Kubińska, Teksty Drugie 3 (2002): 61.

15 Eve Kosofsky Sedgwick. "Shame, Theatricality, and Queer Perfomativity: Henry James's The Art of the Novel," in Eve Kosofsky Sedgwick and Adam Frank, Touching Feeling. Affect, Pedagogy, Performativity (Durham - London: Duke University Press, 2003). 
The story opens innocently:

It was my thirty-fourth time attending the The Csárdás Princess - and because it was late, I cut in line and went straight to the ticket lady: "Dearie, one gallery seat, aquick." Then someone grabbed me by the collar and unceremoniously pulled me back from the counter and put me in my place, the tail end of the line, that is. My heart raced, my breath caught in my chest - is not this something savage, to be taken by the collar in a public place? But I turned my head back: the culprit was a tall, perfumed, well put together gentleman with a neatly groomed mustache. Talking with two elegant ladies and another gentleman, he looked over his freshly purchased tickets. They all looked at me - I had to say something. ${ }^{16}$

Over the course of a single paragraph, Gombrowicz manages to establish an affective essence of the plot. The nameless protagonist breaks the rules of social interaction, "the law of sequence, one of the essential rules of organized public spaces."17 A minor offence and yet one incredibly vexing for other people participating with us in everyday social rituals. Then, one of them reacts accordingly. We might call the reaction a classic interpellation if it were not for the fact that it is not a verbal act, but a physical one (Althusser's classic example involved a policeman interpellating through the use of "Hey, you!"). Notice the protagonist not reacting in any way (he does not protest against his treatment or try to break free from the stranger's hold). The reaction, or, more precisely, the revenge, will come much later. It is as if, moments after his offence, he accepts his punishment - for two reasons. Firstly, he is aware of his crime against laws governing social interaction. Secondly, and equally possibly, his acceptance may stem from the potentially high station of his accuser, the identity of his status expressed in his actions (these relations of symbolic power are important insofar as they will return in different forms in nearly all of the stories collected in the Memoirs).

As a result of these actions, the protagonist is ashamed. Moreover, he is humiliated, as the shaming takes place in a public setting, before dozens of bystanders. No wonder, then, that he uses the word "savage" to describe it. The

16 Witold Gombrowicz, "Tancerz mecenasa Kraykowskiego," in Witold Gombrowicz, Bakakaj i inne opowiadania (Kraków: Wydawnictwo Literackie, 2002), 5. Emphasis mine. From here on out, I will be using the letter T followed by the page number to denote citations from Solicitor Kraykowski's Dancer.

17 Łapiński, Ja, Ferdydurke, 12. In the cited chapter, Zdzisław Łapiński performed a classic analysis of Solicitor Kraykowski's Dancer from the perspective of E. Goffman's theories. 
word choice will be particularly relevant given the fact that the seemingly minor offence in the foyer will eventually lead to someone's (self-)destruction. Shame can kill. So can public humiliation: "At least forty pairs of eyes and faces were staring at me - my heart raced, voice caught in my throat [...]" [T, 6].

Verbalized by the attacker in a theatrical manner, his reasons for the assault are not as self-evident as it may seem: "Go on, to the end of the line with you. Order! Europe!" Turning to the ladies, he observed: "One has to edify the masses, constantly, otherwise we will never outgrow being a nation of Zulus" [T, 6]. Thus Solicitor Kraykowski (although then we have no idea it is him) justifies his assault using metaphors taken straight out of the colonial imaginarium. Europe, a bastion of orderliness and "proper form," is juxtaposed with "savage" and "immature" Zulus. And let us not forget the important role that feminizing and demasculinizing the Other played in colonizing discourse. This approach, described by Edward Said as one of many orientalizing strategies, was used by Otto Weininger to portray Jews. Similarly, the great debate over women's literature, started by Irena Krzywicka's critical reading of Maria Kuncewiczowa's novel, ${ }^{18}$ quickly devolved into a squabble over the effeminate nature of "immature" Poland. Can we, therefore, presume that this colonially coded speech conceals an accusation implying the unmanliness of the protagonist who unceremoniously approaches the ticket lady and showers her with effeminate diminutions? That meaning may be valid but does not necessarily have to be. Nevertheless, we need to keep in mind that - as evidenced by a number of authors - demasculinizing the male subject is one of the most efficient ways to embarrass and humiliate him.

It is not without import, then, that one of the first acts in the protagonist's crusade against Kraykowski is a clearly gendered affront. The next day, after a sleepless night in the course of which he "went over the theater scuffle many, many times" [T, 7] in his head, the protagonist sends solicitor Kraykowski a bouquet of roses and repeats the gesture soon thereafter to further clarify his intent. He buys a small bunch of flowers from a vendor and then "casts a couple of shy violets on the ground below his feet" [T, 8-9]. To bolster his interpretation of these passages, Zdzisław Łapiński invokes Maria Jehanne Wielopolska whose 1938 opus Social Customs authoritatively states: "Never send flowers or sweets to men (excluding actors or stage singers)."19

18 Subsequent texts in this discussion have been collected by Joanna Krajewska in her anthology, Jazgot niewieści i męskie kasztele. Z dziejów sporu o literaturę kobiecq w dwudziestoleciu międzywojennym (Poznań: Wydawnictwo Poznańskiego Towarzystwa Przyjaciół Nauk, 2000).

19 Maria z Colonna Walewskich Wielopolska, Obyczaje towarzyskie (Lwów: Państwowe Wydawnictwo Książek Szkolnych, 1938), 121: as quoted in Łapiński, Ja, Ferdydurke, 13. 
Indeed, the protagonist commits a gender transgression. He sends a bouquet of roses and then a handful of pansies to a man. And not just any man, but one that fully and comfortably inhabits society's gender and class structure, which the novel repeatedly reiterates. He sends the flowers to a lawyer brimming with prestige, someone who acts out the scenarios that society assigns him with irreproachable elegance. And this carefully selected and deliberate gesture is supposed to embarrass or humiliate him. He is supposed to be made to feel like a woman, moreover a woman who is the object of a man's affections: who else would be "frivolously" throwing "shy" violets (notice the gendered stylistic flair) under someone's feet other than a man in love? Thereby, the protagonist deliberately selects gestures supposed to upend the heterosexual norm and humiliate solicitor Kraykowski by emasculating and feminizing him. And, lest we forget, all of these actions are a sort of mimetic revenge, an attempt to get even for what happened the day before at the theater. They are "pastiche rather than parody."20 Thus, we can surmise that the gender aspect definitely played a significant role in the protagonist's own humiliation in the opening of the story, at least in the protagonist's own opinion.

The opening short story deals with reaction to humiliation - with embarrassing the perpetrator of an earlier embarrassment. With a peculiar relationship between two men based on mutual shaming. Because the protagonist did not react to the theater foyer altercation with aggression or alienation but with profuse politeness (courteous bows, attempts at soliciting a cab) - he considers himself the victor in this symbolic game of affects: "I felt myself strangely calm" $[\mathrm{T}, 7]$. Later on he continues to deploy the strategy and commits to an escalation. It may seem, however, that after his sleepless night, the protagonist shifts towards what we may - somewhat excessively - call a "schizoid position," meaning that he ever more clearly sees himself as an object of his own actions (which splendidly rhymes with the grotesque effect from a stylistic standpoint).

\section{Shame and Identity}

But what is shame, really? How does it work? Why, as in the case of the Dancer, are its effects so pronounced sometimes? Silvan Tomkins, one of the fathers of affect theory, included the following passage in the introduction to his examination of the "shame-humiliation dyad":

20 The entire quote from Zdzisław Łapiński, in proper context: "The dancer's deeds are as annoying as mockery and as selfless as an homage. The dancer's mockery is of a special kind - it is pure repetition of the solicitor's gesture, without the exaggeration, so as far as the writing is concerned, it's pastiche rather than parody." Łapiński, Ja, Ferdydurke, 13. 
If distress is the affect of suffering, shame is the affect of indignity, of defeat, of transgression, and of alienation. Though terror speaks to life and death and distress makes the world a vale of tears, yet shame strikes deepest into the heart of man. While terror and distress hurt, they are wounds inflicted from outside which penetrate the smooth surface of the ego; but shame is felt as an inner torment, a sickness of the soul. It does not matter whether the humiliated one has been shamed by derisive laughter or whether he mocks himself. In either event he feels himself naked, defeated, alienated, lacking in dignity or worth. ${ }^{21}$

Together with Adam Frank, Sedgwick prepared and edited a collection of writings from the rather unknown Harvard psychologist to look for possible interpretative avenues that would allow them to transcend dominant patterns of Freudian psychoanalysis (and its Eros-Thanatos binary) and particularly Lacanian psychoanalysis. ${ }^{22}$ In this respect Tomkins's affect theory could have fit the bill, especially given the fact that his work, organically and without assuming presupposed anti-homophobic positions, manages to avoid entanglement with "heterosexist teleologies" (in stark contrast to Freud and Lacan). ${ }^{23}$ It does not presume the existence of a necessary heteronormative ideal which the subject should strive towards, whether consciously or not, regardless of the timeline. Tomkins considers shame one of the proto-affects, or a primary affect, whereas Sedgwick, in her commentary and interpretative efforts, emphasizes the connection between the experience of shame and the interpellation of identity. And that is exactly what happened (to use that particularly od d phrase) to the "dancer." The inflicted shame interpellated identity whose sense stemmed solely from that negative affect.

In her essay on Henry James's The Art of the Novel, Sedgwick writes:

21 Sylvan Tomkins, "Shame-Humiliation and Contempt-Disgust," in Shame and Its Sisters. A Silvan Tomkins Reader, ed. Eve Kosofsky Sedgwick and Adam Frank (Durham - London: Duke University Press, 1995), 133.

"It would be plausible to see a variety of twentieth-century theoretical languages as attempts, congruent with this one, to detoxify the excesses of body, thought, and feeling by reducing the multiple essentialist risks of analog representation to the single, unavowedly essentialist certainty of one or another on/off switch. The Lacanian calculus of phallic presence or absence would be only the most blatant of these, but the critique of Lacan [...] exhibit[s] the same structure." Eve Kosofsky Sedgwick and Adam Frank, "Shame in the Cybernetic Fold: Reading Silvan Tomkins," in Shame and Its Sisters, 20. 
But in interrupting identification, shame, too, makes identity. In fact, shame and identity remain in very dynamic relation to one another, at once deconstituting and foundational, because shame is both peculiarly contagious and peculiarly individuating. ${ }^{24}$

The dancer - let us stay with this odd term for now - as a male subject, should identify with other men, particularly with an exemplary specimen like the solicitor. But nothing of that sort takes place. On the contrary, the protagonist clearly does not identify with hegemonic models of masculinity (neither do characters in the other short stories in the anthology). The clearest indication of this refusal is found in the eponymous description: the dancer - implying transgression of traditional masculine behaviors, in stark contrast to solicitor Kraykowski's stalwart embodiment of these behaviors and standards.

What, then, can be said of the identity of the protagonist himself? As noted by Segdwick, the most conventional way of distinguishing shame from guilt (although Tomkins does not press the dichotomy) presumes that guilt attaches to what we have done, whereas shame sharpens our sense of what we are. ${ }^{25}$ That does not mean, however - and Sedgwick explicitly states as much - that shame is "the place where identity is most securely attached to essences, but rather that it is the place where the question of identity arises most originarily and most relationally."26

This may not be the place to discuss subtle theoretical differences, including those between essentialist and constructivist approaches to identity. It should be noted, however, that in the opening story of Gombrowicz's literary debut, shame sharpens the protagonist's sense of his own identity - whether it be the dancer, freak, epileptic (and thus non-normative in the motor sense), or queer - given the fact, moreover, that the connection between non-heterosexual identities and stigma ${ }^{\mathbf{2 7}}$ and shame has a long history, documented across a large number of writings.

What does the protagonist do? How does he shame the solicitor after being shamed by him, exposed as careless, disorganized, effeminately insolent, simply too flamboyant, or theatrically flamboyant even? Each subsequent

24 Sedgwick, "Shame, Theatricality," 36.

25 Ibid., 37.

26 Ibid., 37.

27 The second story in the anthology, Jakub Czarniecki's BriefMemoir, is an ironic and painful story about stigma. 
attack - as the protagonist engages in something akin to stalking - unfolds as if playing out on stage, with its own script and appropriate props. ${ }^{\mathbf{2 8}}$

Initially, while still in the theater, he bows politely to the solicitor, when it would seem that lobbing phlegm would be his chosen course of action. Then comes an equally cultured request for a shared cab ride, emphasizing the theatrical inappropriateness of the situation and acting wholly against the intuitive scenario one would undertake in an embarrassing situation. It would be completely natural for the protagonist to flee the situation, along the vector of affect, but instead, "in the last possible instant (may it be forever blessed)," $[\mathrm{T}, 6]$ he decided to stay.

His plan for retributive shaming takes final shape over the course of one sleepless night. The protagonist sends the solicitor a bouquet of flowers, thus employing the most effective shaming device - a gender-based one. As we have already established, the heterosexual scenario presumes that red roses are what a man sends to a woman he adores. He treats Kraykowski as one would a woman, and that action is supposed to humiliate him. The protagonist stalks the solicitor, steeping himself in the act, and does so with a passion that is difficult to define. "Oh, I could spend hours staring at that place on his neck where his hair give way to the whiteness of his neck" [T, 8]. This fetishization of the flesh implies a degree of ardor that transcends mere fascination. It is essentially a sign of being lovestruck, as Roland Barthes explained in "Tip of the Nose," a chapter in his A Lover's Discourse. ${ }^{29}$ A fetishizing synecdoche of the object of desire. Shortly thereafter - due to the roses having "no effect" - he decides to push things further and throw a handful of violets at the solicitor's feet. Such a theatrical gesture befits shy youths vying for the affections of schoolgirls more than dancers and solicitors. This violation of heteronormativity, naturally, is supposed to further humiliate Kraykowski. The stalking continues. The next episode takes place in a restaurant, a public place, and takes a particularly theatrical form. What we witness is a feat of mimicry, a masterful performance of imitation. The solicitor makes an order:

- Appetizers, caviar... mayonnaise... fowl... pineapple cubes - black coffee, Pommard, Chablis, cognac, and liqueurs.

28 The issue of theatricality and performativity (also in the context of postcolonial and queer theory) is Gombrowicz's later works is explored most lucidly in Michael Goddard, "The Performativity and the Theatricality of Form in Gombrowicz's Theater and Postwar Novels," in Gombrowicz, Polish Modernism and the Subversion of Form (West Lafayette: Purdue University Press, 2010), 65-105.

29 Roland Barthes, A Lover's Discourse. Fragments, trans. Richard Howard (New York: Farrar" Straus, and Giroux, 1978), 25-28. 
So did I.

- Caviar - mayonnaise - fowl - cubed pineapple - black coffee, Pommard, Chablis, cognac, and liqueurs" [T, 9].

Earlier, the solicitor had not paid the slightest attention to the protagonist, but now he probably has to, given the provocation. The text, however, does not clearly lay out the reasoning. The protagonist does not so much challenge as parodies the behaviors of a well-off, urbane, naturally unpretentious man, ${ }^{\mathbf{3 0}}$ one secure in his station in the bourgeois order. But there is something more to the protagonist's behavior, a relational and gendered surfeit. According to popular stereotypes, boys only pull the hair of girls they like, in order to attract their attention and express their equivocal affect. In a similar vein, the protagonist vies for the solicitor's attention, going so far as to accept the considerable financial burden of repeating the solicitor's euphonically pleasing order to the waiter. Let us be frank - if we were to forget the beginning of the short story, we would have to acknowledge that the relationship increasingly resembles infatuation, including all the typical symptoms of that particular emotional state (tremulous anticipation, somewhat irrational attempts at attracting attention, expensive gifts, and a synecdochal fetishizing of the body of the object of affection). ${ }^{31}$

Subsequent theatrical scenes of embarrassing the solicitor further reinforce that strange effect. Following his feats at the restaurant, the protagonist will buy mille-feuilles for Kraykowski prior to the solicitor's own visit to the pâtisserie. The object of desire is forced to accept the gift against his own will, and is thus shamed by unwanted love, punished by suspect adoration. From the standpoint of the psychotic yet ironic protagonist-narrator, however, the entire fracas still looks more like infatuation than stalking: "I will not describe all that has happened here, alas, it is impossible to describe all. It was as the sea - timeless, swelling throughout the day, often throughout the night. It was wild, like when we once sat across each other in the tram; and sweet, when I could do some favor for him - other times it was amusing. Amusing, sweet, and wild? - Yes (...)" [T, 12].

Obviously, the solicitor considers these actions parts of a retaliation campaign and reacts as one would expect - aggressively. He swings a cane at our

30 How wonderfully he leaned over! How deftly he made his cocktail! He was so elegant, making his jokes, the toothpick between his teeth!" $[T, 10]$.

31 As proof, let us quote the following sensual passage: "[...] I spied on him through the storefront window as he put them [milles-feuilles] in his mouth, gently as to not stain his outfit with the cream, and then licked his fingers or wiped them with a napkin" [T, s. 12]. 
dancer. But it is exactly in his negativity-steeped. upended world that the climax of ecstasy takes place.

I was speechless. I was happy. I took it like holy communion and closed my eyes. In silence - I bent over and offered my back. I waited - going through a handful of moments so utterly perfect that they have to mean my days are numbered. When I uncoiled myself, he was leaving in a hurry, his cane clattering on the ground. With a heart full of grace and blessing, I made my way back through the empty streets. Not enough, I thought, not enough! I need more - more!" [T, 14].

The adoration of the object of desire concludes - as it should - with a fulfilling climax. With orgasmic bliss marked with a masochistic streak. What was supposed to inflict pain is now a source of pleasure. We should also mention here that masochism, a boon of early twentieth-century developments in psychology, was named after Leopold von Sacher-Masoch, the Lviv-born Austro-Hungarian author of Venus in Furs. Despite the gaudy cover art that the novel's editions were usually given ${ }^{\mathbf{3 2}}$ (which was supposed to position it among so-called "low culture" genres) - Venus in Furs is a subtle story about romantic love. That is also the reading of Gilles Deleuze which he presented in his famous essay, Coldness and Cruelty. ${ }^{33}$ Deleuze interprets the novel through the lens of the peculiar contract between Wanda and Severin. The vision of masochism that emerges from Gombrowicz's story (and the issue will be brought up in Dancer two more times) is more or less consistent with the Deleuzian interpretation: it is an attempt on the part of the protagonist to enter into a contract with the fascinating, yet cold and cruel solicitor. The contract is masochistic in nature and is built on a foundation of primal shame, which is later reproduced and multiplied. But it is not sadomasochism. In Deleuze's interpretation, sadomasochism essentially does not exist; to put it differently - there are no separate and complementary sadistic and masochistic positions. Quite the contrary, the two imply completely different sorts of contracts. And this interpretation is also true in Gombrowicz's work: the dancer wants to bind himself to the solicitor with a masochistic contract, but the latter tries as hard as he can to remain unbound. And not because he is not a "sadist," but because he is just not interested.

See the cover for the Polish edition, Leopold von Sacher-Masoch, Wenus w futrze (Łódź: Wydawnictwo "Res Polona," 1989). 
The signum of masochist ecstasy will appear in the short story twice more: when the protagonist approaches the solicitor, offering his back to him but receiving no blows, ${ }^{34}$ and one final time towards the story's conclusion when the protagonist, still chasing the object of his desires, finds himself in the Eastern Carpathians, half-dead from physical and emotional exhaustion, and decides (in what is to be his ultimate ecstasy and final retribution) that his dead body is to be dispatched to Kraykowski himself.

However, as the narrative unfolds, masochist fantasies gradually blend with the arrangement of an emotional triangle. Initially, the "binary" relationship connects the dancer and the solicitor via negative affect. The protagonist, however, quickly arranges a triangle. The word "arranges" seems most appropriate in this context, because the protagonist tries to include a woman in the interplay between him and his object. And rather than involving the solicitor's wife, he homes in on the doctor's wife, because he can sense - like a perfectly tuned monitor - the direction in which the desires of his object are flowing.

Triangles like these are nothing new in prose dealing with love and desire. On the contrary - in his classic volume Deceit, Desire and the Novel René Girard claims that the triangle is the most privileged model in European realist prose. This is one of the arguments on which Eve Kosofsky Sedgwick based her concept of "male homosocial desire," which she posited in Between Men. The triangle arranged in the Dancer, however, strangely departs from the Girardian model. In Gombrowicz's story, the male-female-male triangle is constituted by the beloved and the lover who is supposed to be bound to another man who could be his worthy rival. The latter determines the value of the beloved, and the actions of the dancer seem to be almost a parody of this particular model.

In the first reproachful letter to the doctor's wife, the protagonist describes Kraykowski in ways befitting an infatuated lover: "Are you indifferent to this build, the way this flesh moves, these modulations, this smell? And you still deem yourself a woman? If I were you, I'd fulfill his every whim and command he uttered at my poor, meager, dull, female body" [T, 13]. In the following letter he adds an important note, graphically exposed in the novella: "As far as perfume goes, "Violette" is the only choice. He likes it" [T, 15].

Thus, the dancer attempts to make solicitor Kraykowski a mutual object of both their (mostly) erotic desires. That is what he needs the doctor's wife for. He even tries to substitute his own person for hers. Undoubtedly, these

34 This passage seems to be the most revealing example of Deleuzian masochistic ecstasy: "Indeed, he [Kraykowski] leaves after a couple of minutes with two other gentlemen, and then I approach him and silently present my back. [...] I close my eyes, brace my shoulders, and wait, hopeful - but nothing happens" $[T, 16]$. 
actions are intended to embarrass Kraykowski (by feminizing him through the mention of "Violette" perfume on the one hand, and suggesting a homosexual relationship on the other). The symbolic reward of this peculiar game (which amounts to stalking, regardless of the way we frame it) is the humiliation of the object of affection. And all of this is undertaken by a subject given to more and more psychotic tendencies. We should note, however, that Gombrowicz's male-female-male erotic triangle is markedly different from the Girardian model. Girard, rather uncritically, essentially made his model patriarchal in nature. Two competing men should be jealous of the woman's affections. In Dancer, that model is more or less upended. Young Gombrowicz seemingly acts as if he has recognized the classic model for what it is (Girardian, commonsensical, patriarchal, heteronormative) and then deliberately parodies it.

The ending of the debut anthology's opening story closely resembles one of the final scenes in Witold Gombrowicz's final pre-war effort, Possessed, thus creating inadvertent bookends. In Dancer, the fantasizing subject gives his dead self up to the object of his affections, one that was previously bound to a woman; whereas in Possessed, Laszczuk offers his bound self to the lover of his mistress. Male-male-female triangles with a masochistic bent - either deliberate or not - seem to carry significance in Gombrowicz's early work.

However, I believe that this particular stage of interpretation should not conclude with the assertion that Solicitor Kraykowski's Dancer is a coded homosexual story, or that it is a story about gay jealousies, as put by Kazimierz Wierzyński in Tadeusz Kępiński's memoirs. ${ }^{35}$ At first glance, however, something else emerges from the story - namely, how quickly and naturally the normative model of relationships between men quickly turns "suspect," "queer," and insufficiently heterosexual. The story begins with a wholly understandable situation: an older, stately, hegemonically positioned man disciplines a younger, more disorganized, and still rather undefined lad. This is an obvious and culturally intelligible motif, easily recognizable across a broad range of narratives - from the biological (the dominant male in a pride of lions), through the psychoanalytical (actions of the father figure towards the son), up to the anthropological (the establishment of a new order by the young males who perpetrate a seemingly necessary patricide). In Gombrowicz's story, that obvious relationship is turned upside down very easily, naturally, as if simply by the grace of its movement along a Möbius strip. It is turned upside down and made strange. Made queer. 
This dynamic of the story corresponds to the remarks made by Sedgwick in Epistemology of the Closet. Male homosexuality should not necessarily be understood from an essentialist standpoint (here: the spark that brought the queer relationship to a boil was a negative affect); the definitional limits are unclear and inconsistent, filled with holes left by the shapes of male heterosexuality. As put by Sedgwick herself: "[...] constructions of modern Western gay male identity tend to be, not in the first place «essentially gay», but instead (or at least also): in a very intimately responsive and expressive, though always oblique, relation to incoherences implicit in modern male heterosexuality." ${ }^{\mathbf{3 6}}$ The "dance" around solicitor Kraykowski can be considered a specific emblem of that thesis.

Translation:Jan Szelagiewicz

36 Eve Kosofsky Sedgwick, Epistemology of the Closet (Berkeley: Berkeley University Press, 1990),145. 